\section{Influenza A (H1N1)-induced ischemic stroke in a child: case report and review of the literature}

\author{
ROBERTA CALZEDDA • MANUELA CECCARELLI • \\ FRANCESCA PRIOLO • LUCA MASSIMI • PIERO VALENTINI • \\ PIETRO FERRARA - ANTONIO CHIARETTI
}

\author{
ANTONIO CHIARETTI ( $\square) \bullet$ \\ ROBERTA CALZEDDA • \\ MANUELA CECCARELLI • \\ FRANCESCA PRIOLO • \\ PIERO VALENTINI • \\ PIETRO FERRARA \\ Department of Pediatrics \\ Catholic University of the Sacred Heart \\ A. Gemelli Hospital, Rome, Italy \\ Largo Gemelli, 1 - 00168 Roma, Italy \\ Phone: (+39)3496989047 \\ E-mail: achiaretti@yahoo.it \\ LUCA MASSIMI \\ Pediatric Neurosurgery \\ Catholic University of the Sacred Heart \\ A. Gemelli Hospital, Rome, Italy
}

\begin{abstract}
Ischemic stroke is an important cause of death and long term morbidity in children. Viral respiratory infections are emerging as important risk factors responsible for ischemic stroke in this age group. The direct action of virus against cerebral vessels, autoimmune reactivity, and increased production of cytokines are advocated as the main factors for causing ischemic stro$k$. This study can be useful for clarifying some molecular aspects of H1N1 virus infection in children.

We report on the case of a H1N1-induced ischemic stroke in a Caucasian 2 year-old female. The cerebrospinal fluid samples showed the positivity of polymerase chain reaction for influenza $A$ (H1N1) infection, confirmed also by pharyngeal swab culture. Increased levels of cerebrospinal fluid interleukin 6 and interleukin $1 \beta$ were also detected.

H1N1 virus infection has been identified as an important cause of neurological involvement in children. The findings of increased levels of Interleukin 6 and interleukin $1 \beta$ in the cerebrospinal fluid of this child with H1N1 induced-ischemic stroke seems to validate the role of pro-inflammatory cytokines as crucial mediators of cerebral thrombus formation.
\end{abstract}

Key words: children, $\mathrm{H} 1 \mathrm{~N} 1$ influenza virus, interleukins, ischemic stroke

\section{Introduction}

Ischemic stroke is among the top 10 causes of death in children and an important cause of long term morbidity. (1) Focal neurological deficits, such as hemiplegia, are the most common signs in children, but headaches, speech difficulties, and seizures are also described. (1) About one half of ischemic strokes occur in children with no risk factors, but it can be associated with a variety of conditions, such as congenital heart disease, hematologic and vascular disorders, and infections. (1) Over the last years, several reports of viral respiratory infections have been emerging as important risk factors. (2) H1N1 virus infection was identified as a cause of respiratory infections, ranging from self-limiting to severe illness, both in adults and children. A small percentage of children develop more severe symptoms, such as pneumonia and neurological involvement. Several hypotheses to explain this particular virulence of $\mathrm{H} 1 \mathrm{~N} 1$ were advocated, including down-regulation of type 1 interferon expression, apoptosis, and hyper induction of pro-inflammatory cytokines. (3) Increased production of pro-inflammatory cytokines has also been observed in experimental models of brain ischemia, as well as in patients with acute ischemic stroke. (4) Cytokines, such as interleukin-6 (IL-6) and interleukin-1 $\beta$ (IL-1 $\beta$ ), appear to be crucial mediators of such responses. IL-6 levels rise in both serum and cerebros- pinal fluid (CSF) after ischemic stroke and elevated IL-6 expression has been associated with greater stroke severity and early neurological worsening. IL-1 $\beta$ stimulates the synthesis of tissue factor (TF) from monocytes and endothelial cells activating the coagulation cascade toward thrombus formation. According to the roles of pro-inflammatory cytokines in the formation of ischemic stroke, we evaluated the CSF levels of IL- 6 and $\mathrm{IL}-1 \beta$ in a child with $\mathrm{H} 1 \mathrm{~N} 1$ to clarify eventual correlations between these molecular markers and cerebral ischemia. Only a few cases of $\mathrm{H} 1 \mathrm{~N} 1$ induced-ischemic stroke and neurological involvement have been reported in the literature. We also performed a review of the literature of all pediatric cases with neurological involvement related to this condition. 


\section{Case report}

A 2 year-old Caucasian female was admitted to the emergency room of our hospital because of acute onset of left hemiparesis and persistent weakness. Five days earlier she developed a dry cough with elevated fever $\left(39.5^{\circ} \mathrm{C}\right)$. The examination revealed an awake and nervous child with increased heartbeat and respiratory frequency, weakness of left face, arm, and leg with hypertonia (left spastic hemiparesis) and speech difficulties. On admission, blood exams showed alteration of leukocyte count $\left(2820 / \mathrm{mm}^{3}\right)$. C Reactive Protein, electrocardiogram, chest X-Ray, and non contrasted brain computed tomography were negative. Electroencephalogram (EEG) revealed moderate slow anomalies in the right cerebral hemisphere. Early lumbar puncture highlighted an increased dropflow speed. The CSF samples, submitted for biochemical analysis, were normal, but virological examinations showed the positivity of polymerase chain reaction (PCR) for influenza A (H1N1) infection and also the presence of H1N1 RNA copies (> 500 copies $/ \mathrm{mL}$ ). Pharyngeal swab culture confirmed infection with Influenza A virus, which was identified, by PCR, as a particular H1N1 'variant'. Moreover, to measure interleukin levels, CSF samples were centrifuged for $10 \mathrm{~min}$ at $5,000 \mathrm{rpm}$ and the supernatants were immediately stored at $-70^{\circ} \mathrm{C}$ until analysis. As controls, we used CSF samples collected from 5 children, age related to the H1N1 patient, with the diagnosis of head injury (2 patients) and viral meningoencephalitis (3 patients) who had ischemic stroke as a complication of their disease. IL-1 $\beta$ and IL- 6 were measured using commercial immunoenzymatic kits (Human Quantikine by R\&D Systems). In the H1N1 patient we found significantly $(p<0.001)$ higher levels of IL-6 $(135.5 \mathrm{pg} / \mathrm{mL})$ and IL- $1 \beta$ (20.2 pg/mL) with respect to controls (figure 1,2). In the H1N1 infected child, treatment with Oseltamivir was started after the results of lumbar puncture were received. Two days after admission, the first magnetic resonance image (MRI) revealed a massive ischemic area in the right parietotemporal region along with lateral ventricular compression (figure 3a). Magnetic resonance angiography highlighted focal occlusion in the origin of the right middle cerebral artery (MCA), with a lack of terminal arteries representation right after the trifurcation (figure 3b). Treatment with Mannitol and Acetylsalicidic acid was started. Biochemical exams, homocysteine, coagulation tests and auto-immunity screenings (ANA, anti-ds DNA, anti-ANCA) were negative. Screenings for thrombophilia showed normal values of Protein C $(73 \%$ with normal range $70-140 \%$ ) and Protein S (62\% with normal range 54-110\%) activity. Factor VIII was 140\% (normal range $70-140 \%$ ), Factor V-Leiden, PT mutation G20210, Lupus Lyke AntiCoagulant, anti-cardiolipin antibodies, anti-protrombin antibodies, and anti $\beta_{2}$ glicoprotein antibodies were negative. Transthoracic echocardiogram and doppler sonography of cervical vessels were also negative. Microbiological serology for Varicella zoster virus (VZV), Cytomegalovirus (CMV), Epstein-Barr virus (EBV), Herpes simplex virus (HSV), Mycoplasma, Borrelia, Rickettsie, Coxsackie, Influenza B, Parainfluenza 1,2,3, Echovirus, Respiratory Syncytial Virus (RSV), and Adenovirus were negative or showed previous contact. Eighteen days later, a follow-up MRI highlighted evolution of the lesion to a sub-acute phase and showed a focal ische-

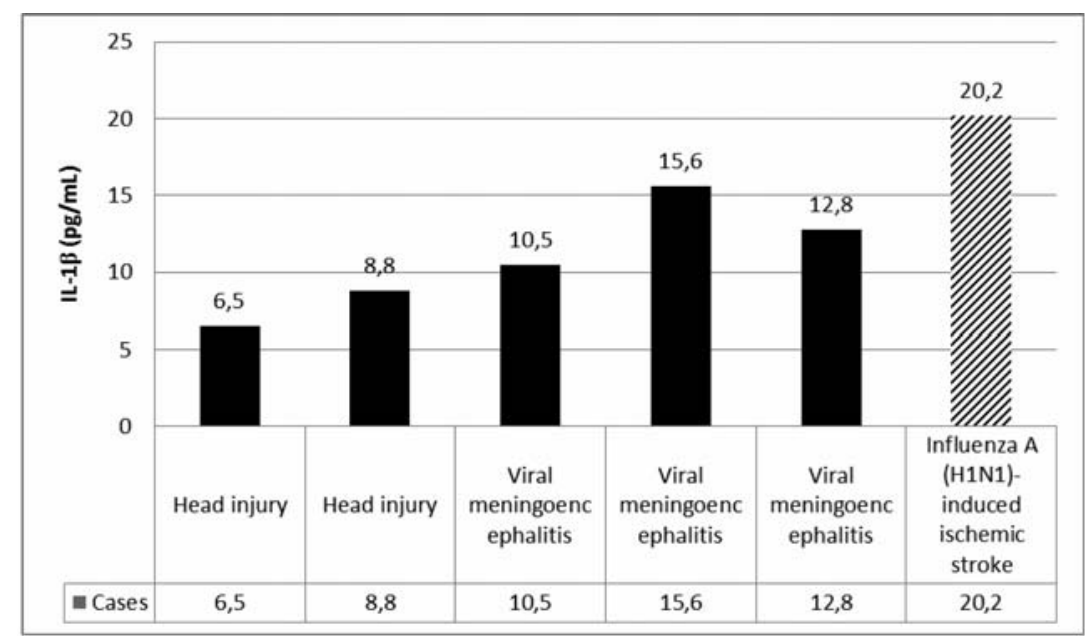

Figure 1. IL-1b cerebrospinal fluid levels in influenza A (H1N1)-induced ischemic stroke and in controls.

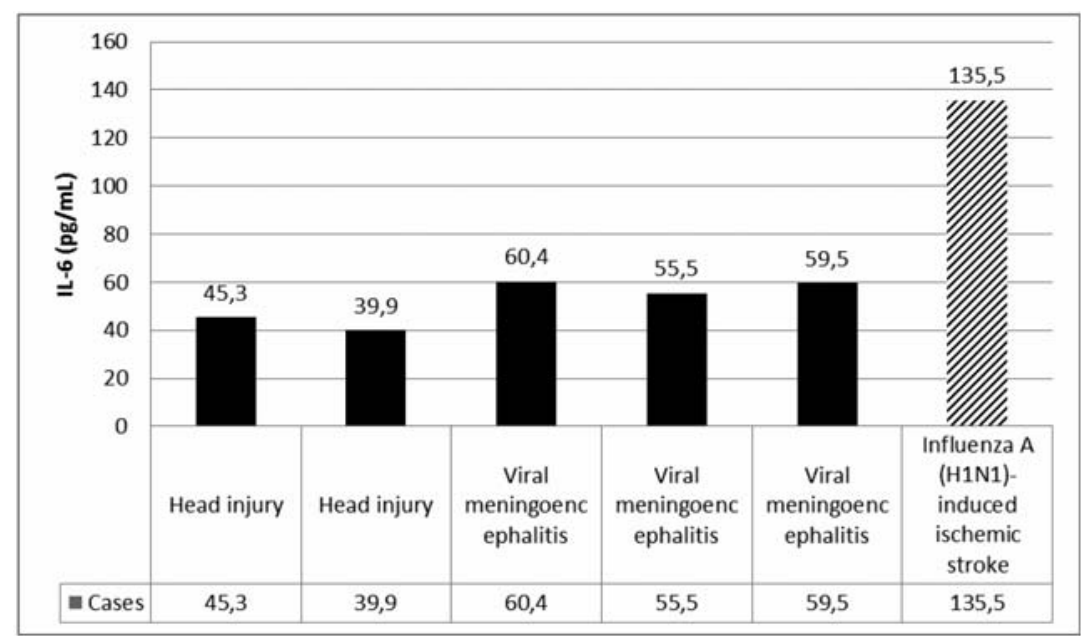

Figure 2. IL-6 cerebrospinal fluid levels in influenza A (H1N1)-induced ischemic stroke and in controls. 

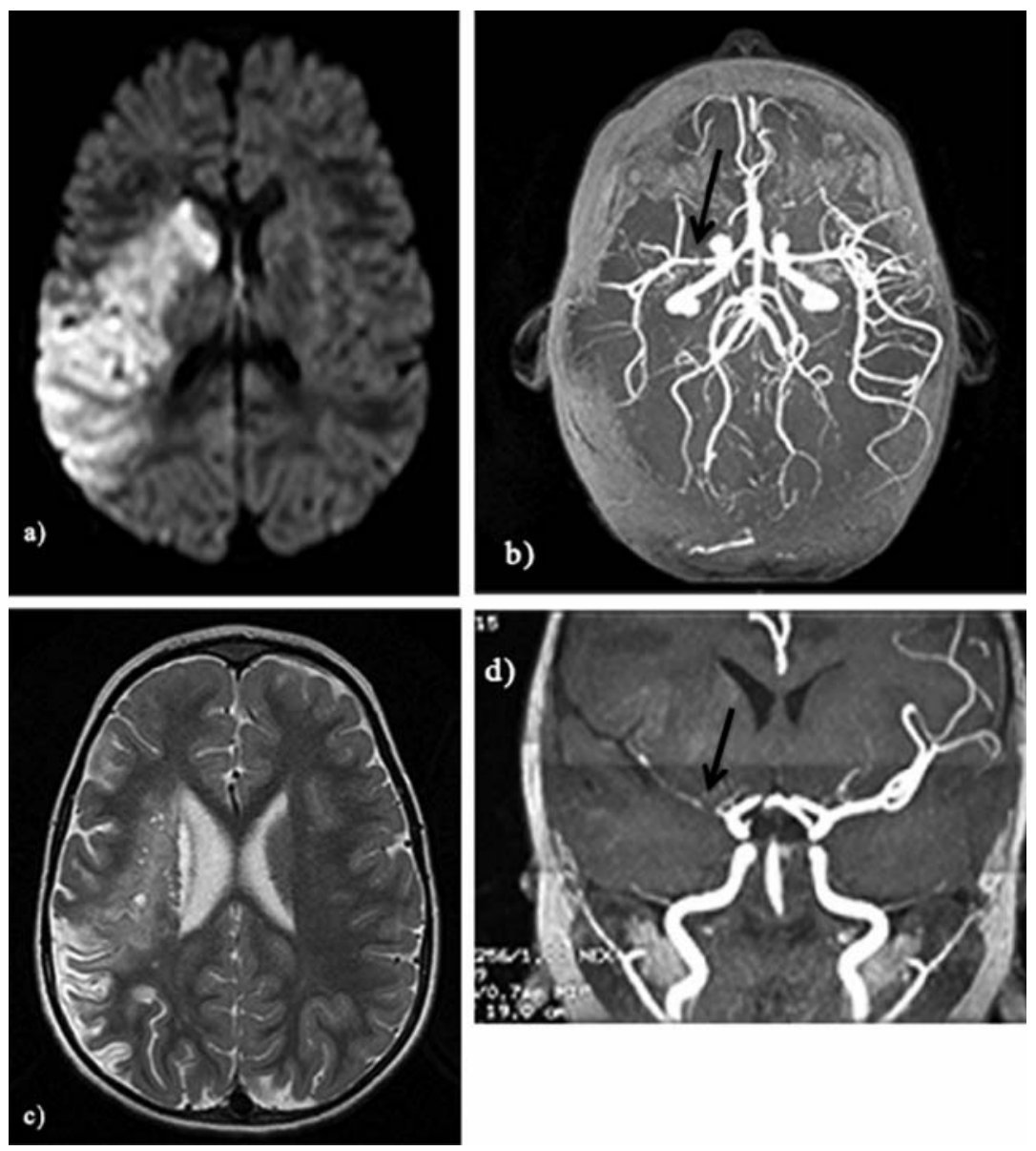

MCA, middle cerebral artery; MRI, magnetic resonance imaging.

Figure 3. MRI evolution. a) Massive ischemic area in the right parietotemporal region along with lateral ventricular compression; b) Magnetic resonance angiography highlighted focal occlusion in the origin of the right middle cerebral artery, see black arrow; c) Follow-up MRI highlighted evolution of lesion to sub-acute phase; d) Angiography confirmed focal occlusion of the right MCA origin and the lack of terminal vessels (see black arrow).

mic area in the cerebral peduncle that was missing in the previous MRI (figure 3c). Magnetic resonance angiography confirmed the focal occlusion of the right MCA origin and the lack of terminal arteries (figure 3d). Based on her clinical improvement, the patient was discharged 23 days after admission, with the recommendation to continue therapy with acetylsalicidic acid. One month later, anticardiolipin antibodies, anti $\beta_{2}$ glicoprotein antibodies, antinuclear antibodies, anti-ANCA antibodies, $\lg \mathrm{G}$ and IgM vs Borrelia burgdorferi, protein $\mathrm{C}$ and $\mathrm{S}$ activities, and coagulation tests were in the normal range. $\mathrm{A}$ follow-up EEG was unchanged. After 4 months from discharge the brain MRI did not highlight any lesion evolution, while the left arm movement impairment persisted along with a slight limp. The child's speech was normal.

\section{Discussion}

To the best of our knowledge, only a few cases of $\mathrm{H} 1 \mathrm{~N} 1$ induced-ischemic stroke and neurological involvement have been reported in the literature (table 1). In those cases a direct action of $\mathrm{H} 1 \mathrm{~N} 1$ infection on cerebral vessels, autoimmune reactivity, or increased production of cytokines were hypothesized. (5-9) Different reports highlighted the role of cytokines as responsible for inflammation injury of cerebral vessels in patients with ischemic stroke and virus infection, as also demonstrated by infecting a mouse model with human influenza A (H1N1) virus. (10) However, it is still unclear whether cytokine-related inflammation is a causal mechanism or a secondary phenomenon induced by the ischemic process. H1N1 infection causes the activation of the host macrophages and lymphocytes determining the release of pro-inflammatory cytokines. (3) Cytokine up-regulation may cause epithelial cell damage by increasing the production of nitric oxide synthase and cyclo-oxygenase, and by favoring the release of the excitatory amino acids and neurotrophins in both experimental and clinical models of cerebral ischemia and viral meningoencephalitis. (11) In particular, IL-1 $\beta$ and IL-6 have been identified as specific markers of neuro-inflammatory mechanisms in different models of acute brain injury. (10) IL-1 $\beta$ is a major link between inflammation and coagulation; indeed, it is able to stimulate the synthesis of TF from monocytes and endothelial cells. On the other hand, IL-6 contributes to post-ischemic inflammation via the release of adhesins and matrix metalloproteinases responsible for leukocyte adhesion and contributing, together with IL-1 $\beta$, to the activation of the coagulation cascade toward thrombus formation. (4) Our results are consistent with these experimental and clinical findings; our child with $\mathrm{H} 1 \mathrm{~N} 1$-induced ischemic stroke elicited an early and more intensive production of $\mathrm{IL}-1 \beta$ and $\mathrm{IL}-6$ in the CSF than controls, suggesting that this up-regulation exerts a key role in the development of the neuro-inflammatory mechanism responsible for ischemic stroke. Although this study does not provide sufficient evidence to support a definitive statement of the source of the measured CSF cytokine increase in this patient with $\mathrm{H} 1 \mathrm{~N} 1$ virus infection, we believe that this report could contribute to demonstrating that cerebral damage is, at least partially, cytokine mediated concurring to clarify some pathophysiological mechanisms related to ischemic stroke in $\mathrm{H} 1 \mathrm{~N} 1$-infected patients. 
Table 1. Pediatric cases of Influenza A (H1N1)-related neurological involvement and cerebral ischemic stroke.

\begin{tabular}{|c|c|c|c|c|c|c|c|c|}
\hline REF. & $\begin{array}{r}\text { Year of } \\
\text { observation }\end{array}$ & Sex & Age & Symptoms & $\begin{array}{r}\text { Coagulation } \\
\text { tests }\end{array}$ & Familiarity & $\begin{array}{r}\text { Nasal- } \\
\text { Pharyngeal } \\
\text { Swab } \\
\text { Cultures }\end{array}$ & MRI Findings \\
\hline 5 & 2009 & M & $4 y$ & $\begin{array}{r}\text { Dry cough, } \\
\text { rhinorrhea, } \\
\text { fever, myalgia, } \\
\text { chills, weakness, } \\
\text { speech } \\
\text { difficulties }\end{array}$ & Unrevealing & $\begin{array}{r}\text { Negative } \\
\text { for stroke at } \\
\text { young age, } \\
\text { deep venous } \\
\text { thrombosis, } \\
\text { pulmonary } \\
\text { embolism, } \\
\text { spontaneous } \\
\text { abortion }\end{array}$ & $\begin{array}{r}\text { PCR positive } \\
\text { for Influenza } \\
\text { A Virus }\end{array}$ & $\begin{array}{l}\text { Sub-acute infarct of } \\
\text { the left middle } \\
\text { cerebral artery. } \\
\text { Angiography: focal } \\
\text { partial occlusion of } \\
\text { left middle cerebral } \\
\text { artery origin }\end{array}$ \\
\hline 8 & 2009 & M & $2 y$ & $\begin{array}{r}\text { Seizure, apathy, } \\
\text { drowsiness, } \\
\text { hemiplegia }\end{array}$ & Normal & Negative & $\begin{array}{r}\text { PCR positive } \\
\text { for H1N1 }\end{array}$ & $\begin{array}{r}\text { Hyperintensities } \\
\text { with restricted } \\
\text { diffusion at the top } \\
\text { of right frontal lobe. } \\
\text { Angiography: } \\
\text { normal }\end{array}$ \\
\hline 9 & 2009 & F & $12 y$ & $\begin{array}{r}\text { Fever, seizures, } \\
\text { speech } \\
\text { difficulties } \\
\end{array}$ & Normal & Negative & $\begin{array}{r}\text { PCR positive } \\
\text { for H1N1 }\end{array}$ & $\begin{array}{l}\text { Acute necrotizing } \\
\text { encephalopathy }\end{array}$ \\
\hline 6 & 2010 & $F$ & $3 y$ & $\begin{array}{r}\text { Fever, focal } \\
\text { convulsion, loss } \\
\text { of consciousness }\end{array}$ & Normal & Negative & $\begin{array}{r}\text { PCR positive } \\
\text { for H1N1 }\end{array}$ & $\begin{array}{r}\text { Bilateral } \\
\text { perirolandic } \\
\text { hyperintensity with } \\
\text { restricted diffusion } \\
\text { and hyperintense } \\
\text { lesions in both } \\
\text { thalami }\end{array}$ \\
\hline
\end{tabular}

MRI, magnetic resonance imaging; PCR, polymerase chain reaction; REF, references; Y, years.

\section{REFERENCES}

1. Lopez-Vicente M, Ortega-Gutierrez S, Amlie-Lefond C, Torbey MT. Diagnosis and management of pediatric arterial ischemic stroke. J Stroke Cerebrovasc Dis 2010;19:175-83.

2. Grau AJ, Buggle F, Becher H, Zimmermann E, Spiel M, Fent T, et al. Recent bacterial and viral infection is a risk factor for cerebrovascular ischemia: Clinical and biochemical studies. Neurology 1998;50:196-203.

3. Chiaretti A, Pulitanò S, Barone G, Ferrara P, Romano V, Capozzi D, et al. IL-1 $\beta$ and IL-6 upregulation in children with H1N1 influenza virus infection. Mediators Inflamm 2013;41:102-8.

4. Fassbender K, Rossol S, Kammer T, Daffertshofer M, Wirth S, Dollman M, et al. Proinflammatory cytokines in serum of patients with acute cerebral ischemia: kinetics of secretion and relation to the extent of brain damage and outcome of disease. J Neurol Sci 1994;22:135-9.

5. Bell ML, Buchhalter JR. Influenza A-associated stroke in a 4-year-old male. Pediatr Neurol 2009;31:56-8.

6. Haktanyr A. MR imaging in novel influenza A (H1N1)-associated meningoencephalitis. Am J Neuroradiol 2010;31:394-5.

7. Honorat R, Tison C, Sevely A, Cheuret E, Chaix Y, Claudet I. Influenza A (H1N1)-associated stroke in a 9-month-old child. Pediatr Emerg Care 2012;28:368-9.

8. Li X. Influenza A (H1N1) virus infection associated with hemiplegia. Indian J Pediatr 2010;77:1338-9.

9. Lyon JB, Remigio C, Milligan T, Deline C. Acute necrotizing encephalopathy in a child with H1N1 influenza infection. Pediatr Radiol 2010;40:200-5.

10. Wang G, Zhang J, Li W, Xin G, Su Y, Gao Y, et al. Apoptosis and proinflammatory cytokine responses of primary mouse microglia and astrocytes induced by human H1N1 and avian H5N1 influenza viruses. Cell Mol Immunol 2008;5:113-20.

11. Chiaretti A, Antonelli A, Piastra M, Genovese O, Polidori G, Aloe L. Expression of neurotrophic factors in cerebrospinal fluid and plasma of children with viral and bacterial meningoencephalitis. Acta Paediatrica 2004;9:1178-84. 